\title{
EFFECT OF PIOGLITAZONE AND FLUOXETINE ON NEUROPATHIC PAIN INDUCED EXPER- IMENTALLY IN DIABETIC RATS
}

\author{
By \\ Amany N. Ibrahim MD and Amro El-Karef MD* \\ Trom \\ Pharmacology Department, Faculty of Medicine, Benha University and \\ * Pathology Department, Faculty of Medicine, Mansoura University
}

\begin{abstract}
Diabetic neuropathic pain, an important microvascular complication in diabetes mellitus, is recognized as one of the most difficult types of pain to treat due to underlying neural pathological changes such as inflammation and fibrosis. It is not possible to use a single drug as a first-line treatment for diabetic peripheral neuropathic pain. The aim of this work is to study the neural pathological changes and tissue levels of proinflammatory cytokines, TNF- $\alpha$ and IL6 that may underlie the different types of neuropathic pain (tactile allodynia and thermal hyperalgesia) and to explore the effects of pioglitazone and/or fluoxetine on these changes. Sixty adult male white albino rats were assigned into two main groups, diabetic group with induction
\end{abstract}

of diabetes by single intra-peritoneal injection of streptozotocin with high cholesterol diet and non-diabetic group fed on normal diet. Each main group was divided into subgroups ( $n=6$ rats each) as follows: [l] control, with no treatment; [II] subjected to peripheral sciatic nerve ligation (PSL) only with no treatment; [III] PSL with pioglitazone treatment; [IV] PSL with fluoxetine treatment and [V] PSL with pioglitazone and fluoxetine combined treatment. All subgroups were tested before, at day 7 and day 14 after PSL for tactile allodynia and thermal hyperalgesia followed by measurement of nerve tissue levels of TNF- $\alpha$ and IL-6, quantification of collagen deposition and macrophages counting. We found that PSL significantly increased inflammatory cell infiltration

MANSOURA MEDICAL JOURNAL 
mainly macrophages and collagen deposition with significant increase of nerve tissue levels of TNF- $\alpha$ and IL-6 in both groups. These changes were associated with significant increase of tactile allodynia and thermal hyperalgesia. Administration of pioglitazone and/or fluoxetine significantly decreased both macrophages infiltration and collagen deposition and nerve tissue levels of TNF- $\alpha$ and IL-6. These effects were associated with significant attenuation of tactile allodynia and thermal hyperalgesia produced by PSL in both diabetic and non-diabetic groups but fluoxetine alone had weaker effect in diabetic group. These results suggested that macrophages infiltration and collagen deposition with associated elevation of tissue proinflammatory cytokines could be a cause of neuropathic pain and administration of pioglitazone and fluoxetine can attenuate neuropathic pain by abolishing these changes.

\section{INTRODUCTION}

Neuropathic pain is characterized by pain in the absence of a stimulus and by reducing nociceptive thresholds so that normally innocuous stimuli produce pain (Scholz et al., 2007). Diabetic neuropathic pain, an important microvascular complication in diabetes mellitus, is recognized as one of the most difficult types of pain to treat (Chong et al., 2007). The management of peripheral diabetic neuropathy consists of excluding other causes of painful peripheral neuropathy, maximizing diabetic control and using medications to alleviate pain (Chong et al., 2007). It is not possible to nominate a single drug as the first-line treatment for diabetic peripheral neuropathic pain. Numerous studies using animal models have proposed candidates for therapeutic targets to reduce neuropathic pain. However currently, there are no good pharmacotherapies for neuropathic pain (Park et al., 2007). Proinflammatory cytokines and the mRNA of TNF- $\alpha$ and IL-1 $\beta$ increased in the brain associated with painassociated behavior in the rat models of neuropathic pain (Watkins et al., 2003). Peroxisome proliferatoractivator receptor (PPAR) is a ligand activated transcription factor belonging to a nuclear hormone receptor superfamily, containing three isoforms $(\alpha, \beta / \delta$, and $\gamma)$ (Lebovitz et al 2001). PPAR $\gamma$ plays a critical physiological role as a primary lipid sensor and regulator of lipid metabolism. 
Thus, its ligands are clinically used for treatment of some diseases, including type 2 diabetes (LunaMedina et al 2005). Some studies evaluated that; pioglitazone attenuates the development and maintenance of allodynia and hyperalgesia in mice with neuropathic pain due to peripheral nerve injury (Goldberg et al., 2005). Antidepressant drugs are reported to be used as co-analgesics in clinical management of migraine and neuropathic pain (Singh et al., 2001). There is increasing recognition that norepinephrine (NE) and serotonin (5-HT) reuptake inhibitors (NRIs and SRIs) are efficacious in treating some types of pain. Studies have not systematically evaluated the relative activity at the NE and/or 5-HT transporter required for maximal efficacy in rodent pain models (Leventhal et al., 2007). Some proinflammatory cytokines contribute to neuropathic pain TNF- $\alpha$ and IL- 6 are expected mediators underlying tactile allodynia and thermal hyperalgesia induced by peripheral nerve injury (Moalem et al., 2006). Thus, the aims of the present work were to explore the effects of pioglitazone or/ and fluoxetine on tactile allodynia and thermal hyperalgesia in neuropathic pain as well as on the patho- logical changes induced experimentally in non-diabetic and diabetic rats and to clarify their possible neuroimmune mechanism of action.

\section{MATERIALS AND METHODS} 1- Drugs and chemicals:

-Streptozotocin (STZ) powder creamy white: (Sigma Chemicals Co., U.S.A).

-Urethane (Ethyl Carbamate); (Prolabo, Paris) white crystals.

-Fluoxetine powder (Misr Co., Egypt)

-Pioglitazone powder (Unipharma, Egypt)

-Carboxy-methyle cellulose (powder)

(El Nasr Pharmaceutical Chemicals Co.)

-Ray Bio ${ }^{\circledR}$ Mouse IL-6: Ray Biotech.U.S.A.

-MEDGENIX TNF-? EASIA Kit.

\section{2-Animals:}

Adult male albino rats $(n=60)$, weighting 150-200 g. They were brought from (Experimental Animal Breeding Farm, Helwan - Cairo) .All animals were housed in controlled laboratory condition at $20-25 \mathrm{C}$ in a $12 \mathrm{~h}$ light/dark cycle and had free access to standard laboratory chow (El-Nasr Company, Abou-Zaabal, Cairo, Egypt) and water. They have acclimatized for one week and were caged (6/cage) in fully ventilated

MANSOURA MEDICAL JOURNAL 
room (at room temperature) in pharmacology department, Benha Faculty of Medicine. All experimental protocols were approved by the committee of Benha University.

\section{3 - Study Design:}

After acclimatization for 1 week, the rats were assigned into 2 groups' non-diabetic and diabetic group. Each group was subdivided into five experimental groups, 6 rats each and treated for 14 days as follow:

Group (I): Normal control group. Fed normal diet, did not receive any drugs but the sciatic nerve of right lateral hind limb in rats was exposed, and not subjected to ligation.

Group (II): None-treated peripheral sciatic nerve ligation (PSL) group. Fed 40\%cholesterol diet. Peripheral sciatic nerve subjected to ligation according to the modified method of Seltzer Z et al. 2004.

Group (III): Pioglitazone-treated group. Received pioglitazone $(25 \mathrm{mg} / \mathrm{kg} /$ day $)$ by gavage according to Maeda et al., 2008.

Group (VI): Fluoxetine-treated group. Received fluoxetine (30mg/kg/day) by subcutaneous injection (Jett et al., 1997).

Group (V): Pioglitazone+fluoxetinetreated group. Received pioglitazone (25mg/kg/day) by gavage and fluoxetine (30mg/kg/day) by subcutaneous injection.

Diabetes was induced by a single intraperitoneal injection of streptozotocin (STZ $60 \mathrm{mg} / \mathrm{kg}$ ) dissolved in cold 0.1 mole citrate buffer $(\mathrm{pH} 4.5)$ after fed the rats with high fat diet for 2 weeks as a model for type 2 diabetes (Islam et al., 2007) 72 hours after STZ injection, diabetes was confirmed in rats by showing blood glucose levels increased to $>300$ mg/100 ml (Ganda et al., 1976). The blood glucose concentration was measured using a glucometer from blood samples obtained by tail prick.

\section{4- Surgical procedure}

The procedure used for induction of neuropathic pain was the model adopted by Seltzer Z et al., 2004. Rats were anaesthetized with urethane (1.5-1.75 $\mathrm{g} / \mathrm{kg}$ I.P). The left sciatic nerve was exposed at the upper-thigh level, and the dorsal third to half of the sciatic nerve was

Vol. 42, No. 1 \& 2 Jan. \& April, 2013 
tightly ligated. The wound was then sutured and the rats were allowed to recover in their home cage.

\section{5 -Behavioral tests}

All the behavioral data were recorded before surgery, at day 7 and day 14 for all subgroups. The paw pressure threshold in response to normal innocuous mechanical stimuli was measured by using an analgesimeter (Randall et al., 1957). Rats were situated on the platform under the situation point, so that this is at $5 \mathrm{~mm}$ distance. Once the rats are prepared we activate the start pedal. The values on the display will increase in a progressive way and once the selected algesic response has been reached (shaking of the stimulated rat, vocalization etc.), we free the start pedal. The force $(\mathrm{g})$ being exerted at the moment of freeing the start pedal is considered the end-point of the test. Once the pedal is released, the motor will turn counter-wise, at the same time the value shown at the digital display is transmitted through the RS232 serial connector.

On the other hand, thermal sensitivity was determined by measuring hind-paw withdrawal latencies to a radiant heat stimulus according to
Hargreaves et al., 1988 just before and after 7 days in non-diabetic groups, and 14 days after STZ injection with sciatic nerve ligation.

\section{6 -Estimation of serum TNF- $\alpha$ and} IL-6:

After the behavioral testing on day 7 and day 14 post-surgery, all rats were deeply anesthetized with sodium pentobarbital and the sciatic nerve was dissected $(1 \mathrm{~cm}$ in length, including the ligation region). We determined the change in expression of tumor necrosis factor- $\alpha$ (TNF- $\alpha$ ) and interleukin-6 (IL-6) in the sciatic nerve

a- Estimation of TNF- $\alpha$ by a sandwich ELISA with (MEDGENIX TNF- $\alpha$ EASIA Kit).

TNF- $\alpha$ was determined using a commercially available kit according to the manufacture instructions.

b- Estimation of IL- 6 by ELISA technique using (Ray Bio ${ }^{\circledR}$ Mouse IL6):

By following the manufacture instruction according the protocol of Howord et al., 1992.

\section{7- Histopathological examination:}

After the behavioral testing on day 7 and 14 post-surgery, all rats were deeply anesthetized and the sciatic nerve was dissected, fixed with $10 \%$ formaldehyde; embedded in 
142 EFFECT OF PIOGLITAZONE AND FLUOXETINE etc...

paraffin, cut at $5 \mathrm{um}$, stained with hematoxylin and eosin (H\&E) and with Masson trichrome and examined. The pathologist was unaware of the treatment protocol.

\section{a- Quantification of Fibrotic Areas}

Quantitative analysis of sciatic nerve collagen fibers deposition in masson trichrome-stained tissues was performed by morphometric analysis (James et al., 1990). A total of 10 fields were randomly chosen per mouse and images were taken with a digital camera mounted on a CX41 Olympus optical microscope. Collagenous areas stained with masson trichrome were extracted and analyzed using the NIH Image software. The extent of fibrosis was expressed as the percentage of the stained area relative to the total area. The percentages obtained from the 10 fields were expressed as the mean \pm standard deviation.

\section{STATISTICAL ANALYSIS}

Data are shown as mean \pm S.E.M. The results were analyzed by one way analysis of variant (ANOVA) followed by t-test or turkey test with $\mathrm{p}<0.05$ selected as the criterion for statistical significance. The histopathological data were analyzed and compared using Student's t-test or Mann-Whitney's U test.

\section{RESULTS}

\section{1-Behavior test :}

Peripheral sciatic nerve ligation (PSL) induced significantly tactile allodynia ligation which calculated as the rats showing hind paw withdrawal in response to lower weight (grams) pressure applied to its hind paw. Administration of pioglitazone $(25 \mathrm{mg} / \mathrm{kg}$, orally) daily and combination of pioglitazone and fluoxetine once daily alleviated the tactile allodynia in non-diabetic and diabetic groups. Also, administration of fluoxetine $(30 \mathrm{mg} / \mathrm{kg}$, s.c) once daily significantly attenuated tactile allodynia in non-diabetic rats but, could not successfully improve tactile allodynia in diabetic rats.

Regarding the thermal hyperalgesia, it was observed that peripheral sciatic nerve ligation-induced thermal hyperalgesia as sciatic nerve ligation groups had significantly shorter withdrawal latencies, and this was reversed by pioglitazone administration and combination of pioglitazone and fluoxetine in non-diabetic and diabetic rats. On the other hand, administration of fluoxetine $(30 \mathrm{mg} / \mathrm{kg}$, 
s.c) improved thermal hyperalgesia elicited by peripheral nerve injury in comparison to the control group in non-diabetic rats. But administration of fluoxetine $(30 \mathrm{mg} / \mathrm{kg}, \quad$ s.c) produced no significant improvement in thermal hyperalgesia in diabetic rats (table 1).

2- Production of inflammatory cytokines:

TNF- $\alpha$ and IL- 6 were at a low lev$\mathrm{el}$ in the control group. Sciatic nerve ligation was associated with marked increase in the expression of both cytokines TNF- $\alpha$ and IL-6 in all examined nerve tissue on day 7 and 14. Pioglitazone and fluoxetine, sup- pressed significantly the elevation of both cytokines in all examined tissues (table 2).

\section{3- Histopathological examination}

Sciatic nerve ligation produced inflammatory cell infiltration with increased collagen fibers deposition in the injured sciatic nerve in comparison to normal control group. Administration of pioglitazone and /or fluoxetine showed less inflammatory cell infiltration with significant reduction of collagen deposition in both groups non-diabetic group. But fluoxetine alone show lesser improvement in diabetic group $(P<0.006$ vs. 0.0009 in non-diabetic group (Figure 1A, 1B)

Table (1): showing effects of pioglitazone and fluoxetine on tactile allodynia and thermal hyperalgesia which enhanced by peripheral sciatic nerve ligation

\begin{tabular}{|l|c|c|c|c|}
\hline \multirow{2}{*}{ Groups } & \multicolumn{2}{|c|}{ Threshold (g) } & \multicolumn{2}{c|}{ Latency (S) } \\
\cline { 2 - 5 } & $\begin{array}{c}\text { Non-diabetic } \\
\text { groups }\end{array}$ & $\begin{array}{c}\text { Diabetic } \\
\text { groups }\end{array}$ & $\begin{array}{c}\text { Non- diabetic } \\
\text { groups }\end{array}$ & $\begin{array}{c}\text { Diabetic } \\
\text { groups }\end{array}$ \\
\hline Normal control group & $340.3 \pm 14$ & $310.2 \pm 16$ & $6.8 \pm 1.6$ & $5.9 \pm 2.2$ \\
\hline $\begin{array}{l}\text { Sciatic nerve ligation group } \\
\text { (PSL) }\end{array}$ & $\begin{array}{c}152.8 \pm 8 \\
\mathrm{P} 1<0.05\end{array}$ & $\begin{array}{c}90.8 \pm 8 \\
\mathrm{P} 1<0.05\end{array}$ & $\begin{array}{c}3.2 \pm 0.14 \\
\mathrm{p} 1<0.05\end{array}$ & $\begin{array}{c}3.1 \pm 0.12 \\
\mathrm{p} 1<0.05\end{array}$ \\
\hline Pioglitazone group (25mg/kg) & $\begin{array}{c}260.4 \pm 18 \\
\mathrm{P} 2<0.05\end{array}$ & $\begin{array}{c}270.4 \pm 10 \\
\mathrm{P} 2<0.05\end{array}$ & $\begin{array}{c}4.9 \pm 0.1 \\
\mathrm{p} 2<0.05\end{array}$ & $\begin{array}{c}4.7 \pm 0.1 \\
\mathrm{p} 2<0.05\end{array}$ \\
\hline Fluoxetine group (30 mg/kg) & $\begin{array}{c}280.6 \pm 20 \\
\mathrm{P} 3<0.05\end{array}$ & $\begin{array}{c}160.8 \pm 13 \\
\mathrm{p} 3<0.05\end{array}$ & $\begin{array}{c}3.8 \pm 0.4 \\
\mathrm{p} 3<0.05\end{array}$ & $\begin{array}{c}3.8 \pm 0.19 \\
\mathrm{p} 3>0.05\end{array}$ \\
\hline $\begin{array}{l}\text { Pioglitazone } \\
\text { (25mg/kg)+Fluoxetine(30mg/kg) }\end{array}$ & $\begin{array}{c}305.1 \pm 23 \\
\mathrm{P} 4<0.05\end{array}$ & $\begin{array}{c}290.6 \pm 14 \\
\mathrm{p} 4<0.05\end{array}$ & $\begin{array}{c}5.6 \pm 0.5 \\
\mathrm{p} 4<0.05\end{array}$ & $\begin{array}{c}4.8 \pm 0.13 \\
\mathrm{p} 4<0.05\end{array}$ \\
\hline
\end{tabular}

P1 compares values in control groups with normal values

P2 compares values in pioglitazone group with PSL group

P3 compares values in fluoxetine group with PSL group

P4 compares values in pioglitazone $(25 \mathrm{mg} / \mathrm{kg})+$ fluoxetine $(30 \mathrm{mg} / \mathrm{kg})$ with PSL group

MANSOURA MEDICAL JOURNAL 
Table (2): showing effects of pioglitazone and fluoxetine on sciatic nerve levels of TNF- $\alpha$ and IL-

\begin{tabular}{|l|c|c|c|c|}
\hline \multirow{2}{*}{ Groups } & \multicolumn{2}{|c|}{ Non diabetic } & \multicolumn{2}{c|}{ Diabetic } \\
\cline { 2 - 5 } & TNF- $\alpha$ & IL-6 & TNF- $\alpha$ & IL-6 \\
\hline Normal Control group & $0.25 \pm 0.01$ & $0.08 \pm 0.001$ & $0.03 \pm 0.001$ & $0.12 \pm 0.01$ \\
\hline PSL group & $\begin{array}{c}0.72 \pm 0.013 \\
\mathrm{P} 1<0.05\end{array}$ & $\begin{array}{c}0.25 \pm 0.011 \\
\mathrm{P} 1<0.05\end{array}$ & $\begin{array}{c}0.82 \pm 0.011 \\
\mathrm{P} 1<0.05\end{array}$ & $\begin{array}{c}0.29 \pm 0.012 \\
\mathrm{P} 1<0.05\end{array}$ \\
\hline Pioglitazone group (25mg/kg) & $\begin{array}{c}0.45 \pm 0.03 \\
\mathrm{P} 2<0.05\end{array}$ & $\begin{array}{c}0.16 \pm 0.013 \\
\mathrm{P} 2<0.05\end{array}$ & $\begin{array}{c}0.35 \pm 0.03 \\
\mathrm{P} 2<0.05\end{array}$ & $\begin{array}{c}0.22 \pm 0.011 \\
\mathrm{P} 2<0.05\end{array}$ \\
\hline Fluoxetine group (30 $\mathrm{mg} / \mathrm{kg})$ & $\begin{array}{c}0.46 \pm 0.02 \\
\mathrm{P} 3<0.05\end{array}$ & $\begin{array}{c}0.18 \pm 0.002 \\
\mathrm{P} 3<0.0\end{array}$ & $\begin{array}{c}0.51 \pm 0.014 \\
\mathrm{P} 3<0.05\end{array}$ & $\begin{array}{c}0.21 \pm 0.012 \\
\mathrm{P} 3<0.05\end{array}$ \\
\hline $\begin{array}{l}\text { Pioglitazone } \\
\text { (25mg/kg)+Fluoxetine(30mg/kg) }\end{array}$ & $\begin{array}{c}0.42 \pm 0.004 \\
\mathrm{P} 4<0.05\end{array}$ & $\begin{array}{c}0.13 \pm 0.005 \\
\mathrm{P} 4<0.05\end{array}$ & $\begin{array}{c}0.46 \pm 0.03 \\
\mathrm{P} 4<0.05\end{array}$ & $\begin{array}{c}0.17 \pm 0.005 \\
\mathrm{P} 4<0.05\end{array}$ \\
\hline
\end{tabular}

P1: Significant difference from normal control group

P2 compares values in pioglitazone group with PSL group

P3 compares values in fluoxetine group with PSL group

$\mathrm{P} 4$ compares values in pioglitazone $(25 \mathrm{mg} / \mathrm{kg})+$ fluoxetine $(30 \mathrm{mg} / \mathrm{kg})$ with PSL group

Table (3): showing effects of pioglitazone and fluoxetine on $\%$ of collagen deposition in different groups compared to the normal control group

\begin{tabular}{|l|c|c|c|c|}
\hline \multirow{2}{*}{ Groups } & \multicolumn{2}{c|}{ Non diabetic } & \multicolumn{2}{c|}{ Diabetic } \\
\cline { 2 - 5 } & \% Fibrosis & P-value & \% Fibrosis & P-value \\
\hline Normal Control group & $3.9 \pm 0.16$ & & $3.9 \pm 0.16$ & \\
\hline PSL group & $9.23 \pm 0.73$ & $\mathrm{P} 1<0.0001$ & $9.53 \pm 0.32$ & $\mathrm{P} 1<0.0001$ \\
\hline Pioglitazone group (25mg/kg) & $6.93 \pm 0.82$ & $\mathrm{P} 2<0.0057$ & $7.12 \pm 0.91$ & $\mathrm{P} 2<0.0008$ \\
\hline Fluoxetine group (30 mg/kg) & $6.02 \pm 0.95$ & $\mathrm{P} 3<0.0009$ & $7.83 \pm 0.93$ & $\mathrm{P} 3<0.006$ \\
\hline $\begin{array}{l}\text { Pioglitazone(25mg/kg)+ Fluoxetine } \\
(30 \mathrm{mg} / \mathrm{kg})\end{array}$ & $4.34 \pm 0.72$ & $\mathrm{P} 4<0.0001$ & $5.021 \pm 0.63$ & $\mathrm{P} 4<0.0001$ \\
\hline
\end{tabular}

P1: Significant increased collagen deposition from normal control group

P2 compares \% fibrosis reduction in pioglitazone group with PSL group

P3 compares \% fibrosis reduction in fluoxetine group with PSL group

$\mathrm{P} 4$ compares \% fibrosis reduction in pioglitazone $(25 \mathrm{mg} / \mathrm{kg})+$ fluoxetine $(30 \mathrm{mg} / \mathrm{kg})$ with PSL group

Vol. 42, No. 1 \& 2 Jan. \& April, 2013 

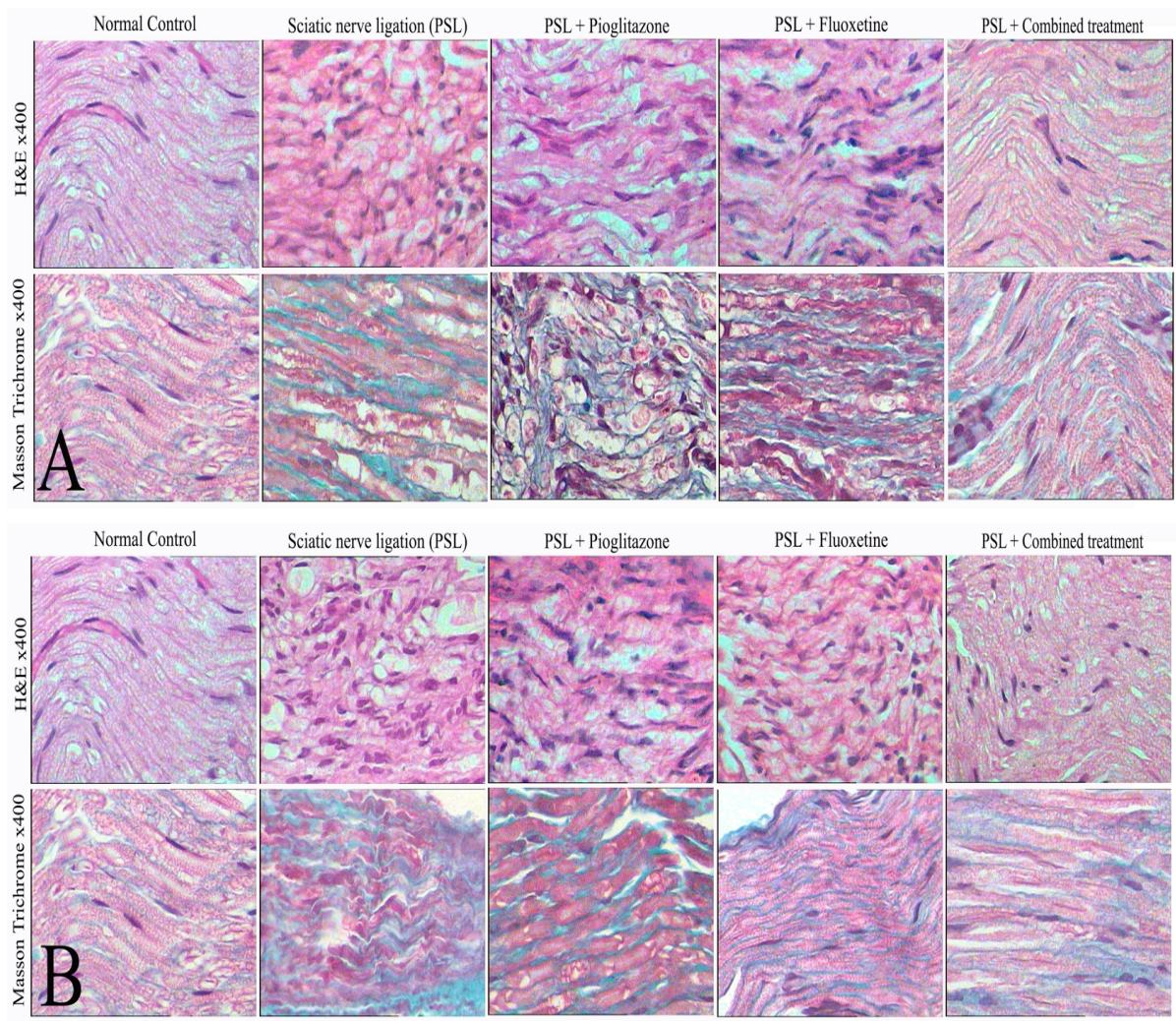

Figure (1): Effects of pioglitazone and fluoxetine on histopathological changes in rats with: A) Non-diabetic peripheral sciatic nerve neuropathy. B) Diabetic groups.

Sciatic nerve ligation produced inflammatory cell infiltration with significant increase in the collagen fibers in the injured sciatic nerve in comparison to normal control group. Administration of pioglitazone and /or fluoxetine decrease the inflammatory cells and significantly reduced the amount of collagen in diabetic and non-diabetic groups but fluoxetine alone showed milder improvement in diabetic group. 


\section{DISCUSSION}

Results of the present work revealed that administration of pioglitazone $(25 \mathrm{mg} / \mathrm{kg} / \mathrm{day})$ attenuated tactile allodynia and thermal hyperalgesia. These results are in agreement with Maeda et al., (2008) who found that pioglitazone attenuated the development and maintenance of allodynia and thermal hyperalgesia in mice with neuropathic pain due to peripheral nerve injury. Also, Papans et al., 2011 reported that pioglitazone has been shown to improve experimental diabetic neuropathy and alleviate neuropathic pain. Wiggin et al., 2008 observed that rosiglitazone reduced oxidative stress and prevented the development of thermal hypoalgesia in streptozotocin-induced diabetic mice. In addition, Churi et al., 2008 found that PPAR ligand-induced activation of spinal PPAR-gamma rapidly reverses nerve injury-induced mechanical allodynia. On contrast to these finding, Shibata et al., 2000 reported that troglitazone was less effective in controlling neuropathy in the Zucker diabetic fatty (ZDF) rats. This difference in our results may be due to uses of different doses and different species of animals.

Vol. 42, No. 1 \& 2 Jan. \& April, 2013
In the present study, fluoxetine significantly attenuated tactile allodynia and thermal hyperplasia. These effects are in line with those reported by Kesim et al., 2006 that fluoxetine showed significant antinociceptive effect in non diabetic mice, but they could not successfully show this effect in diabetic mice. In disagreement with these findings, Sounvoravong et al., 2007 who stated that fluoxetine itself lacks antinociceptive properties in diabetic and sciatic nerve ligation mice, as model of neuropathic pain. Jett et al., 1997 added that fluoxetine $(3-30 \mathrm{mg} / \mathrm{kg}$, s.c) did not inhibit either hyperalgesia or allodynia in formalin model and the L5/ L6 spinal nerve ligation model of neuropathic pain.

Some proinflammatory cytokines contribute to neuropathic pain. TNF$\alpha$ and IL- 6 are accepted mediators underlying tactile allodynia and thermal hyperalgesia induced by peripheral nerve injury (Moalem et al., 2006). Sciatic nerve injury increases the levels of both cytokines in the sciatic nerve, dorsal root ganglion, and spinal cord (Murphy et al., 1995, Deleo et al., 1996, George et al., 1999, and Ignatowski et al., 1999 which agrees with the present study. 
Transcription of both cytokines is partial sciatic nerve ligation. Adminisregulated by transcription factor tration of pioglitzone and fluoxetine binding sites within the promoter. It decreased the histopathological has been reported that promoter activities of both TNF- $\alpha$ and IL- 6 are driven by binding of NF- $\mathrm{KB}, \mathrm{AP}-1$, and STAT, primary proinflammatory transcription factors (Chinetti et al., 2000). We therefore, tested whether pioglitazone and fluoxetine blocked partial sciatic nerve ligation induced up-regulation of both cytokines. Administration of pioglitazone and fluoxetine after PSL reduced increases in the expression level of both cytokines in all examined tissues. These results strongly suggest that pioglitazone and fluoxetine alleviates tactile allodynia and thermal hyperalgesia, at least in part, through inhibiting the upregulated proinflammatory cytokines. These results are in congruent with those of Maeda et al., 2008 who reported that pioglitazone alleviates neuropathic pain through attenuation of proinflammatory cytokine upregulation by perioxsone proliferative activated receptor gamma stimulation.

Finally, histopathological examination of sciatic nerve showed inflammatory cell infiltration with increased amounts of collagen after changes in the sciatic nerve sections of the treated diabetic and non diabetic rats. These results are in line with Takahashi et al., 2011 who reported that, rosiglitazone treatment in the early phase of neuropathic pain significantly alleviated the development of tactile allodynia by regulating macrophage infiltration and production of proinflammatory molecules at the inflamd site.

In conclusion, pioglitazone in combination with fluoxetine may be an effective combination in attenuating diabetic and non-diabetic neuropathic pain through inhibiting the over expression of pro-inflammatory cytokines with subsequent decrease in inflammatory cell infiltration and nerve fibrosis.

\section{REFERENCES}

Chinetti G, Fruchart JC, Staels B (2000) : Peroxisome proliferator-activated receptors (PPARs): nuclear receptors at the crossroads between lipid metabolism and inflammation. Inflamm Res. Oct; 49(10):497-505. 
Chong MS and Hester J (2007) : Diabetic painful neuropathy: current and future treatment options. Drugs 67(4):569-85.

Churi SB, Abdel-Aleem OS, Tumber, KK, Scuderi-Porter H, Taylor BK (2008) : Intrathecal rosiglitazone acts at peroxisome proliferatoractivated receptor-gamma to rapidly inhibit neuropathic pain in rats. J Pain 9:639-649.

Deleo JA, Colbum RW, Nichols M, Malhatora A (1996) : Interleukin-6-mediated hyperalgesia/allodynia and increased spinal IL-6 expression in a rat mononeuropathy model. J Interferon Cytokines Res. 16:695-700.

Ganda OP, Rossini AA, Like AA (1976) : Studies on streptozotocin diabetes. Diabetes. Jul; 25(7):595-603.

George A, Schmidt C, Weishaupt A, Toyka KV, Sommer C (1999) : Serial determina- tion of tumor necrosis factor-alpha content in rat sciatic nerve after chronic constriction injury. Exp Neurol.160:124-132.

\section{Goldberg RB, Kendall DM, Deeg MA, Buse JB, Zagar AJ, Pinaire JA, Tan MH, Khan MA, Perez AT, Jacober SJ; GLAI Study Investiga- tors. (2005) : A compari- son of lipid and glycemic effects of pioglitazone and rosiglitazone in patients with type 2 diabetes and dyslipidemia. Diabetes Care Jul; 28(7):1547-54.}

Hargreaves K, Dubner R, Brown F, Flores C, Joris J (1988) : A new and sensitive method for measuring thermal nociception in cutaneous hyperalgesia. Pain 32:7788.

Howord M and O'Gara A. (1992) : biological properties of interleukin 10. Immunology Today 13:158-200.

Ignatowski TA, Covey WC, Knight PR, Severin CM, Nickola 
TJ, Spengler RN (1999) : Brain-derived TNF-? mediates neuropathic pain. Brain Research, 841, 7077.

Islam MS and Choi H (2007) : Nongenetic model of type 2 diabetes a comparative study. Pharmacology 79 (4):243-9.

James J, Bosch KS, Aronson DC, Houtkooper JM. (1990) : Sirius red histophotometry and spectrophotometry of sections in the assessment of the collagen content of liver tissue and its application in growing rat liver. Liver.; 10:1-5.

Jett MF, McGuirk J, Waligora D, Hunter JC (1997) : The effects of mexiletine, desipramine and fluoxetine in rat models involving central sensitization. Pain Jan; 69 (1-2):161-9.

Kesim M, Duman EN, Kadioglu M, Ulku C, Muci E, Kalyoncu NI, Yaris E (2006) : Antinoceptive effects of fluoxetine and paroxetine with their related actions on glycemia in mice. Neuro Endocrinol Lett. Feb-Apr; 27(1-2):2817.

Lebovitz HE and Banerji MA (2001) : Insulin resistance and its treatment by thiazolidinediones. Recent Prog Horm Res.56:265-94.

Leventhal L, Smith V, Hornby G, Andree TH, Brandt MR, Rogers KE (2007) : Differential and synergistic effects of selective norepinephrine and serotonin reuptake inhibitors in rodent models of pain. $J$ Pharmacol Exp Ther. Mar; 320(3):1178-85.

Luna-Medina R, Cortes-Canteli M, Alonso $M$, Santos $A$, Martínez A, Perez-Castillo A (2005) : Regulation of inflammatory response in neural cells in vitro by thiadiazolidinons derivatives through peroxisome proliferator-activated receptor gamma activation. J Biol Chem. 280:21453-21462.

MANSOURA MEDICAL JOURNAL 
Maeda T, Kiguchi N, Kobayashi Y, Ozaki M, Kishioka S (2008) : Pioglitazone attenuates tactile allodynia and thermal hyperalgesia in mice subjected to peripheral nerve injury. Life Science, Niigata 950-2028.

Moalem G and Tracey DJ (2006) : Immune and inflammatory mechanisms in neuropathic pain. Brain Res Rev, 51:240-264.

Murphy PG, Grondin J, Altares M, Richardson PM (1995) : Induction of interleukin-6 in axotomized sensory neurons. J Neurosci. 15:51305138.

Papans N, Katsiki N, Hatzitolios AL, Maltezos E (2011) : Pioglitazone: a valuable component of combination therapy for type 2 diabetes mellitus. Expert Opin Pharmacother Jul; 12(10):145761.

Park SW, Yi JH, Miranpuri G, Satriotomo I, Bowen K, Resnick DK, Vemuganti $R$
(2007) : Thiazolidinedione class of peroxisome proliferator-activated receptor gamma agonists prevents neuronal damage, motor dysfunction, myelin loss, neuropathic pain, and inflammation after spinal cord injury in adult rats. $J$ Pharmacol Exp Ther. 320:1002-1012.

Randall L.O., and Selitto, J.J. (1954) : Analgesimeter Arch. Int. pharmacodyn. Ther. 111: 409, (1957).

Scholz J and Woolf CJ (2007) : The neuropathic pain triad: neurons, immune cells and glia. Nature Neurosci. 10:1361-1368.

Seltzer Z, Dubner $\mathbf{R}$ and Shir $\mathbf{Y}$ (2004) : A noval behavioral model of neuropathic pain disorders produced in rats by partial sciatic nerve injury. Pain 43:205-218.

Shibata T, Takeuchi S, Yokota S, Kakimoto K, Yonemori F, Wakitani K (2000) : Effects of peroxisomes 
proliferator-activated receptor-alpha and gamma agonist, JTT-501, on diabetic complications in Zucker diabetic fatty rats. $\mathrm{Br}$ Pharmacol. JUN; 130(3): 495504.

Singh VP, Jain NK and Kulkarni SK (2001) : On the antinociceptive effect of fluoxetine, a selective serotonin reuptake inhibitor. Brain Res. Oct 12; 915(2):218-26.

Sounvoravong S, Nakashima MN, Wada M, Nakashima K (2007) : Modification of antiallodynic and antinociceptive effects of morphine by peripheral and central action of fluoxetine in a neuropathic mice model. Acta Biol Hung. Dec; 58(4):36979.

Takahashi Y, Hasegawa-Moriyama M., Sakurai T, Inada E
(2011) : The macrophagemediated effects of the peroxisome proliferatoractivated receptor-gamma agonist rosiglitazone attenuate tactile allodynia in the early phase of neuropathic pain development. Anesth Analg. Aug; 113(2):398404.

Watkins, LR, Milligan, ED,Maier SF (2003) : Glial proinflammatory cytokines mediate exaggerated pain states: Implications for clinical pain. Advances in Experimental Medicine and Biology 521, 1-21.

Wiggin TD, Kretzler M, Pennathur $S$, Sullivan KA, Brosius FC, Feldman EL (2008) : Rosigilitazone treatment reduces diabetic neuropathy in streptozocin-treated DBA/2J mice. Endocrinology Oct; 149(10): 4928-37. 
الملحص العربى

تأثير تآزر الفولوكستين مع بيوجليتازونى على السيطرة على السكر واللمس وفرط الاله الحرارى فى الفئران الغير مصابة بالسكرى والمصابة بالسكرى والمعرضة لإلإصابة بالتهاب العصب الطرفى.

أمانى نصر عبد الهادى إبراهيه و عمرو عوض الكارف

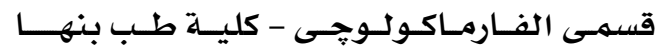

$$
\begin{aligned}
& \text { جامعة بنها وقسم الباثولويىى - كليّة طب المنصورة }
\end{aligned}
$$

آلام الأعصاب الطرفية هو مشكلة هـامـة وخـاصة بـين مرضى السكرى. والعلاقة الدقيقة بـين السيطرة على سكر الدم، وتحسين شدة إعتلال الأعصاب المحيطية مـع السكرى لاتزال مثيرة للجدل .

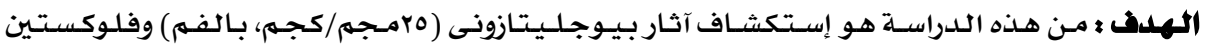
( •مهجم/كجم، تحت الجلد)، والجمع بين الدواءين إما فى جرعة منخفضة (• امجم/كجم) أو إرتفاع جرعة

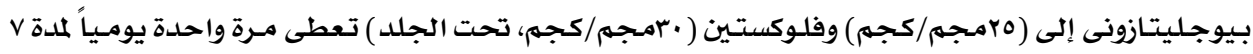
أيـام و عا يومـاً على اللهس وفرط التألهم الحرارية فى نهوذج ألهم الأعصاب السكرى وغير السكرى فى الفئران وآلية العمل الممـكنـة ورصد آثارهـا على مستويـات السكر فى الدم. وقياس عامل تآكل الأورام ألفا فى أنسجة الأعصاب فى الفئران المصابة بالسكرى وغير السكرى . تم توسيم الفعران إلى مجمومتين ؛ احداهما غير مصابة بالسكرى والأخرى مصابة بالسكرى عن طريق الحقن داخل الصفاق بجرعة واحدة

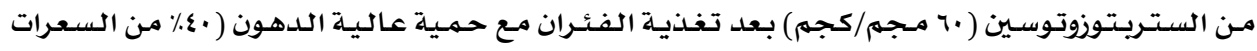
الحـرارية والدهون) لمدة أسبوعين بـاعتبـاره نموذج لمرض السكرى من النوع الثانى. وأكد السكرى فى الفئران 


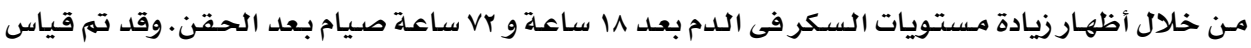
تركيز السكر فى الدم باستخدام عينات دم من وخز الذيل وقياسها بالكلومتر . ثم تم تقسيم الفئران الغير مصابة والمصابة بالسكرى إلى خمسة مجموعات : المجمومة الأولى : مجموعة المراقبة وتشمل ج فئران . المجمومة الثانيح2 المجموعة المصابة بالتهاب الاعصاب الطرفى بلدون أى علاج وتشمل ج فئران .

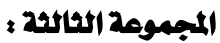
مجموعة البايوجليتازون (0بمجم/كجم) وتشمل ج فئران . المبجمومة الرابش2ح مجموعة الفلوكسيتين (·r مجم/ كجم) وتشمل r فئران

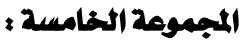
مجموعة البايوجليتازون (0 مجم// كجم) والفلوكسيتين (·r مجم/ كجم) وتشمل r فئران . الفئران لمصابة وغير المصابـة بالسكرى خضعت لربط العصب الوركى. ثم تم قياس اللـمس باستخدام جهاز قياس الألم قبل وبعد الجراحة. وتم تقييم فرط التألم الحرارية السـاخنة باستخدام لوحة فى كل من الفئران المصابة بالسكرى وغيـر مصابة بـالسكرى. وتم قياس مستوى السكر فى الدم لكل المجمـوعات كما تم

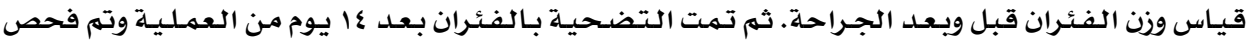
مـجهرى لتحديد التغيرات البـاثولوجية المصاحبـة فى أنسجة الاعصاب وتعيين مستوى عامل تآكل الأورام ألفا فى أنسجة الأعصاب المصابة والغير مصابة بالسكرى

وخلد تبين الاكتى من النتاثج :

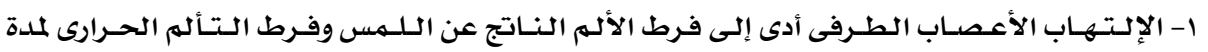
أسبوعين. أما اعطاء بيوجليتازون وحده وفلوكستين وحلده وكلا الدوائين معا لمدة V أيام للفئران الغير مصابة بالسكرى أدى إلى وهن التألم الناتج عن اللمس ووهن التألم الحـرارى، ولكن فلوكستين وحده لا يظهر بنجاح هذه الآثار فى الفئران المصابة بالسكرى بعد ع إيوما من ربط العصب الطرفى . MANSOURA MEDICAL JOURNAL 
ץ-وأمـا اعطاء بيوجليتازون وحلده وفلوكستين وحده كان له آثار ضئيلة على سكر الدم فى الفئران المصابة

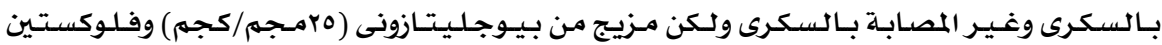
( · ·مجم/كجم) كان لها آثار كبيرة فى سكر الدم فى الفئران المصابة بالسكرى . ب- أن زعطاء البيـوجليتازون أدلى إلى زيـادة وزن الفئران أمـا اعطاء الفـلوكستين فأدى إلى فقـدان للوزن فى كلا من الفئران المصابة بالسكرى وغير مصابة بالسكرى .

ع- مســتوى عامل تـآكل الأورام ألفـا كان مـرتفعـاً فى أنســــة أعصـاب الفئـران المصـابـة والغيـر مصـابـة بالسكرى والمصابة بـالتهاب الأعصاب الطرفى بالمقارنة بالمجموعة الضابطة. أما اعطاء بيوجليتازون

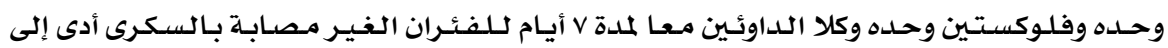
إنخفاض مستوى عامل تآكل الأورام ألفا . ه- التغيرات الباثولوجيـة المصاحبة فى أنسجة الأعصاب كانت فى صورة زيادة فى الخلايا الملتهمة وزيادة فى ترسب الأنسجة الليفية فى الأعصاب والتى تحسنت كثيراً عند المعالجة بهزيج من بيوجليتازونى (0ץمجم/كجم) وفلوكستين (·rمجم/كجم) بالمقارنة باعطاء كلا منهما على حدة .

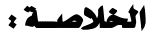

هـا يثـير إلى أن بيوجلسيتازونى وفلوكستين يخفف آلام الأعصاب فى الفئران على حد سواء وذلك من الممكن عن طريق توهين خلوى وإنخفاض مستوى عامل تآكل الأورام ألفا والتى أدت إلى تحسن فى التغيرات المصاحبـة فى الأنسجة وكان هـناك إرتباط بـين مستويـات السكر فى اللدم والتسكين على الرغم من أن الجمـع بين جرعات عالية من كلا من الدوائين يسبب إنخفاض ملحوظ فى مستوى السكر فى الدم. كما أن اضافة الفلوكستين إلى بيوجليتازون منع زيادة الوزن التى يسببها البيوجليتازون فى الفئران .

Vol. 42, No. 1 \& 2 Jan. \& April, 2013 